\title{
Presenting a Model Explaining the Factors Affecting the Faculty Academic Recession at Ardabil University of Medical Sciences
}

\author{
Sousan Salimi Pormehr ${ }^{1}$, Sadraddin Sattari $^{2 *}$, Turan Soleimani ${ }^{3}$ \\ 1,2,3 Department of Educational Sciences, Ardabil Branch, Islamic Azad University, Ardabil, Iran
}

\section{Keywords: \\ Academic Recession, Faculty, University of Medical \\ Sciences}

\section{Received}

20 September 2020

Received in revised form

15 October 2020

Accepted

22 October 2020

*Correspondence:

sadraddin1356@yahoo.com

\begin{abstract}
The purpose of this study was to present a model to explain the factors affecting the academic recession of faculty members at Ardabil University of Medical Sciences, Ardabil, Iran. As a descriptive-survey research having a mixed methods design, this study identifies the relevant indicators, puts forward rating and validation of a model. In the qualitative phase, the population included university experts, faculty members, experts in the field of higher education, and policymakers. We selected 10 people as participants through purposive sampling. In the quantitative phase, all faculty members of Ardabil University of Medical Sciences including 226 people were selected by the complete enumeration method. The data collection instrumentation included an interview and a researcher-made questionnaire. The results of the analysis of interviews with Grounded Theory and content analysis revealed that the factors affecting the academic recession of faculty members at Ardabil University of Medical Sciences include: personal factors (age, IQ, work history, personality traits, marital status, and gender); organizational and environmental factors (type of employment, organizational structure, salary and benefits, governing relationships in promotion, university management, and rules and regulations); psychological factors (lack of success, inappropriate social relationships, not enjoying work, and job stress); work factors (being members of different scientific committees, priority of economic and financial factors among physicians, prioritization of work in the personal surgery office, lack of appropriate incentives and penalties, the value of the title of physician and no need for promotion, and ignoring medical errors), and skill factors (lack of language proficiency, weakness in public speaking, and lack of skill in using specialized software).
\end{abstract}

Higher education is an important sector having a very wide range of influence on other economic, social, cultural, and political institutions and sectors of the society. This is in a situation where rapid and increasing changes in societies such as scientific developments, the emergence of various 
needs, diversity in knowledge and skills required by society, increasing number and change in student composition, innovation and change in higher education, transfer of universities and higher education centers from one geographical space to national, regional, and international levels, the challenge of traditional higher education through international (overseas) higher education, the use of information and communication technology, the establishment of private higher education institutions in the context of the General Agreement on Trade in Services, and the provision of higher education opportunities through campuses and e-universities represent new issues in today's higher education. Academic education is the highest level of education in any country, and along with quantitative developments, basic steps must be taken to improve its quality development. Paying attention to quality is a prerequisite for the dynamism and the focus on the higher education system, and success in this direction will bring developments in efficiency and productivity. Faculty members play the most important role in improving the quality of higher education (Mobini \& Abbaspour, 2014).

Faculty members have a sensitive and important position in society and can be influential to the students. On the one hand, they can have a positive effect on solving problems in the society by conducting research and research projects. On the other hand, a frustrated professor or faculty member cannot establish vitality, security of mind, and stability in the classroom and educational environment, and may eventually think they have nothing to offer. Since having higher level skills is the core of the quality of higher education institutions, it is impossible for a higher education institution to provide high quality education and research in the absence of faculty members benefiting from knowledge, ability, professional capabilities, real commitment, and motivation. Also, preventing the recession in organizations will increase organizational happiness which is in correlation with organizational commitment (Vaseghi \& Ahmadlou, 2019). In recent years, faculty development and faculty academic recession prevention have become an important issue in higher education.

Due to their knowledge and capabilities, faculty members should be provided with conditions to let them perform best in universities and research centers (Çelo, Danaj, Çerkezi, \& ÇELO, 2019). In some cases, due to a variety of factors, faculty members face academic recession and they cannot fulfill the expectations. This is the main focus of the current study.

\section{Theoretical Background}

The issue of recession or plateau in the professional path is part of the working life and refers to the state of cessation in the process of one's progress (Kreuter, 2004). Recession or plateau in the professional path indicates the lack of progress and reduction of individual learning and induces a kind of depression and failure (Khanifar, 2006).

Job plateau or stasis is defined as a point in a job where the possibility of hierarchical promotion is much less. The term recession refers to the feeling of failure or frustration that people experience temporarily or permanently during their career process. Judith Bardwick (as cited in Allen et al., 2014), who first introduced the "burnout" phenomenon, estimates that only one percent of the workforce in their working life is not affected by this phenomenon.

Bardwick believes that the $99 \%$ rule is true in this case, because almost everyone on the way up in the organizational hierarchy in their career path slips into recession. Due to the recent social trend and increase of literacy and number of graduate people, most people slip into recession in 
lower ages. In general, most people reach this stage in the middle of their life and some important issues happen throughout this stage (Burke \& Mikkelsen, 2006).

Career recession is not a new phenomenon; the worrying situation is that its growth rate has started to increase in different organizations. As a social problem, this issue has attracted the attention of many people both from academic and professional perspectives (Allen et al., 2014).

Due to having various duties and responsibilities such as attending meetings and forums, issues related to students, conducting research and long working hours of faculty members, their tasks and expectations interfere because of their job. The faculty members perception of strategic planning is effective on their leaders' performance (Al-Omari, 2020). These cases can have devastating effects and even decisions that can lead to personal failure, lack of enthusiasm for research, low standard of teaching, or unwillingness to upgrade their knowledge in their field and ultimately leading to academic recession (Ahadi et al., 2015).

Important causes of job recession include low salaries and benefits, poor working conditions, high work responsibilities, unreasonable expectations of managers, organizational conflicts, lack of proper feedback, and insufficient authority in the workplace (Mahmoudi \& Qaslani, 2015). Some researchers divide the causes of job recession into three categories: a) individual factors including age, rank, and external locus of control, b) family factors including spouse's job responsibility and family workload, and c) organizational factors including previous successes in the organization, willingness to progress, operational position, supervisor evaluation, and commitment to work (Tremblay \& Roger, 2004).

In a recent study, the basic needs of faculty members have been introduced as appropriate salaries, appropriate research facilities, and budget for research and support (Alrahlah, 2016). Although career recession or disintegration is followed by negative mental inference, it is not necessarily a negative experience. Another study found that work interruptions may be helpful for growth and development of people. In periods of stability and stillness, individuals can master work skills. Therefore, the career plateau may be efficient for individuals (Norouzi, Zare, \& Shir Ali, 2016).

In discussing the effects of recession, it should be noted that career plateau causes dissatisfaction, because continuous upward advancement, job learning and challenge, and ultimately, specialization and potential labor market due to professional skills are important sources of motivation. Advances usually involve the acquisition of benefits such as salary, increases in power, and position. Therefore, many employees use progress as a measure of their success in an organizational environment. But when they realize that their career advancement in the organization is no longer achievable, they will have a negative attitude. In general, research has shown that increased absenteeism, stress, willingness to leave the job, increased job declining levels, decreased job satisfaction and organizational commitment, role conflict, decreased selfesteem, and lack of ability to coordinate with changes, low level of job participation and nondisclosure of initiative are the inevitable consequences of career recession (Norouzi et al., 2016).

Career plateau is used as a prelude to many of the consequences of undesirable work, such as high stress, poor performance, exaction signs, low organizational commitment, and increased decision-making to transfer. Career recession potentially causes frustration among employees because employees who suffer from career recession think that employers have abandoned their jobs (Magner, Welker, \& Campbell, 2011). 
Tabarsa et al. (2014) conducted a study entitled designing and explaining the model of career plateau management in Iranian organizations. The research was descriptive and structural. The population included experts, junior and senior managers from the Ministry of Industry, Mines and Trade (324 people). The results showed that the content plateau does not directly predict the studied results, but through its effect on the types of plateau, it can be effective in job results. In general, the results showed that $13 \%$ of job satisfaction variance, $23 \%$ of psychoanalytic analysis variance, $36 \%$ of variance in the desire for organizational emancipation, and $13 \%$ of organizational commitment variance can be explained by the dimensions of career plateau. The results of this study can provide guidelines for better management of occupational plateau in Iranian organizations.

Saleh Ardestani and SeyedNaghavi (2016) published a study entitled explaining the relationship between career plateau and organizational indifference and the willingness of the staff to leave their jobs. Their research method was based on quantitative and survey studies. They distributed a questionnaire among 355 employees of Iran Insurance Company. Regression and ANOVA statistical techniques were used to analyze the data. The results referred to the career plateau among the staff of Iran Insurance Company. Unexpectedly, there wasn't a close relationship between this phenomenon and willingness of the staff to leave their jobs but it showed a close relationship with organizational indifference.

Shariatnejad et al. (2017) in their research titled identifying and prioritizing the causes of career plateau in governmental organizations using fuzzy Delphi method, identified and prioritized the factors of career plateau in governmental organizations. The population included human resource managers of governmental organizations in Khorramabad, Iran where 25 of whom were selected using purposive sampling. The results consisted of two parts. In the first part, a set of factors causing career plateau was identified and in the second part, the importance and priority of these factors were determined. Their results revealed that lack of sufficient motivation among employees, inability to improve working conditions, few opportunities for promotion, lack of job challenges, ambiguity in work and change in organizational structure were the most important factors in creating career plateau.

Abraham, Nwovuhoma, and Malik (2016) in their study entitled occupational plateau and employee performance in secondary school in Rivers State, aimed to discover the causes and effects of plateau on a person and propose the best strategies for managing the employees who encounter this phenomenon. They concluded that lack of individual ability and skills, low organizational growth, job instability and organizational hierarchy are influential. Also, career plateau causes psychological stress and burnout, depression and lack of commitment to work and high levels of absenteeism among the staff.

Drucker et al. (2015) conducted a study entitled occupational plateau, job satisfaction and professors' commitment at Universities in France. The sample included the performance of 2,028 French scientists, assistant professors and professors in such universities. The study was conducted quantitatively and an online questionnaire was used. Textual data were analyzed using qualitative method. It turned out that despite job satisfaction and commitment, there were some job dissatisfactions. The women slowly feel job plateau, feeling less satisfied than men, and less committed to ongoing commitments. But they are less likely to leave their organization, and older professors are more committed and have a higher level of satisfaction. This study shows a significant relationship between gender and age with job plateau, satisfaction, and commitment. 


\section{Method}

In the present study, which has a practical orientation, the selected research method is a mixed methods approach and the basis of work has been the use of experts and elite's opinions. Data collection methods include library studies, viewing documents, interviewing with centralized group methods and research analysis tools included content analysis through editing data from the centralized groups, and Delphi method. Thus, after conducting preliminary steps using the study of dissertations, articles, related books and the Internet websites, the researcher designed and prepared many open and semi-open questions which were mentioned and discussed in the centralized groups. The extracted results of the centralized groups were analyzed using the classified theme analysis and then by the Delphi technique, which was presented after the final review.

Since the purpose of this study is to provide a model to explain the factors affecting the recession of faculty members, then the research was applied in terms of purpose, because applied research is a research in that theories of the rule of law that are developed in basic research are used to solve problems. Data collection method is also descriptive and survey based. According to the research method, the sample consists of experts at two levels: At the first level (qualitative phase) to identify the factors affecting the recession of faculty members, the sample consists of faculty members and experts in the field of higher education and policy making. In the second level (quantitative phase) for prioritization and validation of the model, the sample consists of 226 faculty members of Ardabil University of Medical Sciences.

In order to sample the first level, the selection of individuals for interview and implementation of Delphi technique was done in a completely purposeful manner and according to their expertise and experience, and includes people who have:

- a prominent position in the field of higher education and human resource productivity,

- taught at least 5 years as a faculty member at the country's universities,

- $\quad$ articles and research projects in the field of higher education,

- the experience of being a member of the Policy Council of the Ministry of Science, Research and Technology, and

- a management background in higher education.

Therefore, 10 participants were selected for interview from higher education experts who were well known professors in the field of higher education.

At the second level, according to the data analysis method for prioritizing the factors affecting the academic recession of faculty members and model validation due to the low sample size and insufficient numbers to perform factor analysis in case of sampling, the total sample size of 226 individuals was considered a desirable number.

As mentioned, the research process consists of two parts, qualitative and quantitative. In the qualitative section, based on content analysis and expert interviews, the initial indexes were identified. Therefore, at this stage, semi-structured interviews and study of texts were used to collect the data.

In the quantitative section, the instrument was the questionnaire, which was used in the first stage to measure the agreement of experts on indicators. In the second stage to finalize, determining the weight of indicators, this instrument was used and the data were collected in different ways and from different places and resources. In this study, the required data were collected in two quantitative and qualitative phases. 
Structural validity has been used to achieve first-level validity. At the second level, face validity has been used to determine the validity of the questionnaire and to examine the form and sentence structure of the questionnaire items. In this way, the prepared questionnaire was given to 10 experts and after consulting them, the necessary corrections were made regarding the wording of the questions and after finalizing the questionnaire items, it was distributed among the sample.

Investigating the reliability of the questionnaire used in the research, the experimental implementation method was used on a random sample. In this way, 30 questionnaires were distributed among the sample individuals and then collected and finally, Cranach's alpha was used to determine the reliability of the mentioned questionnaire.

To design the initial conceptual model of the factors affecting the academic recession of faculty members in a process form, indicators and variables were extracted (actions) from each stage. In accordance with each stage of the research process, the data analysis method was introduced. The general process of doing research is as follows:

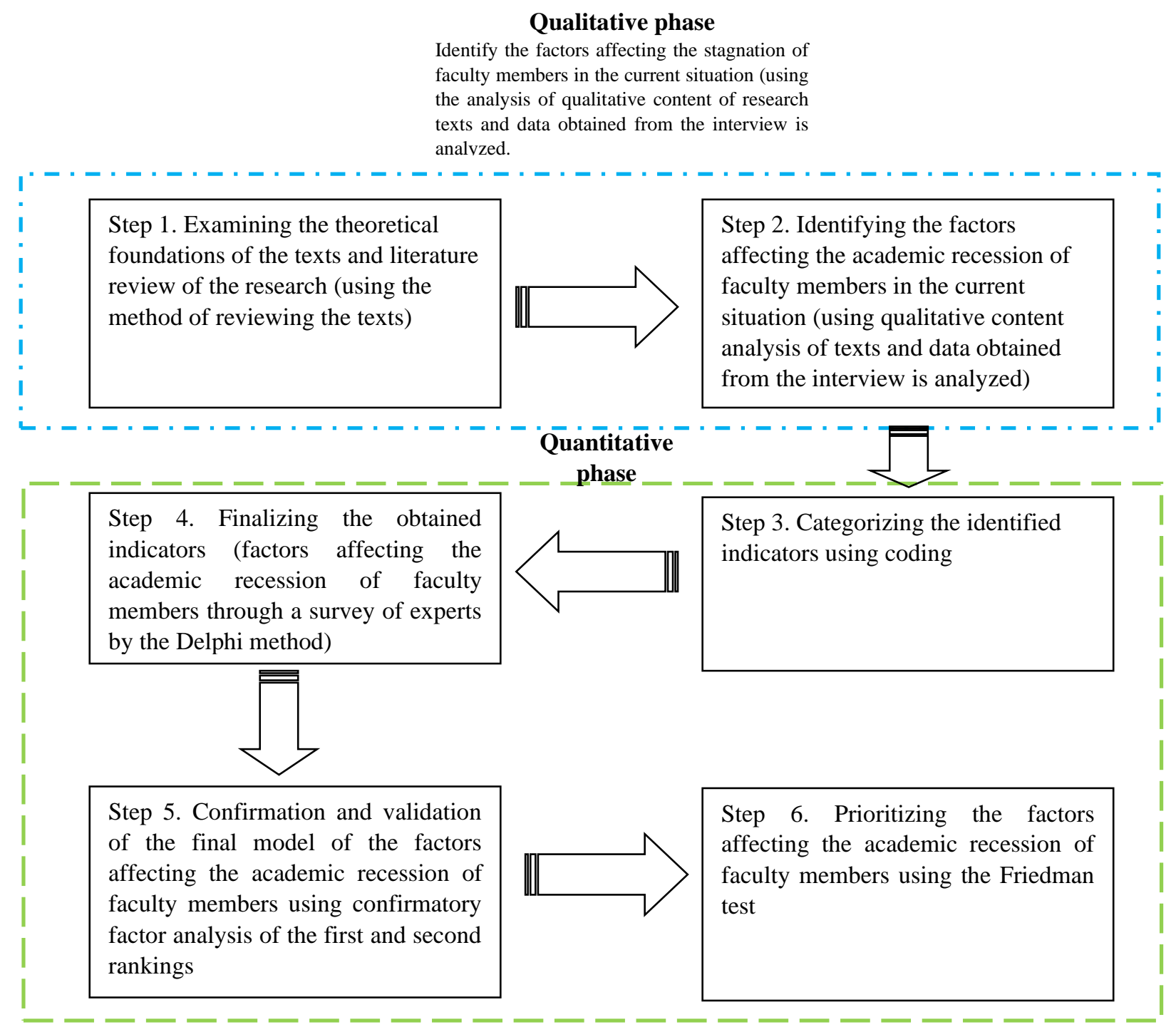

Figure 1. Statistical analysis methods 


\section{Data Analysis and Results First Level (Qualitative Phase)}

Theme analysis was used to analyze the data obtained from the interviews. In this way, the interview texts were first reviewed and coded, and through this, various concepts used in this research were extracted. These concepts are divided according to the apparent content into conceptual categories that are actually symbols. These categories are also presented in terms of different themes.

In this section, the interviews were first carefully examined and the key themes and the most important indicators of the recession of the faculty members of the Ardabil University of Medical Sciences were identified and categorized in three stages: open coding, axial coding, and selective coding.

In the open coding stage, according to the research topic, concepts and factors affecting the recession of faculty members of Ardabil University of Medical Sciences were considered dimensions and basic concepts. Then the existing concepts were identified and classified in terms of open codes (primary category). At this stage, a total of 57 initial codes were extracted.

In the axial coding stage, the sub-themes were related to the main themes. In fact, one of the presented themes was selected as the main theme and the other themes were related to it regularly and systematically. At this stage, the open codes from the previous step were linked to the core code and categorized. At this stage, a total of 51 codes were identified based on the initial codes and their review.

In the selective coding stage, the concepts and themes introduced in the previous stage were systematically and regularly classified and categorized. At this stage, the extracted themes were named in terms of five general concepts and 51 subsets. At this stage, the extracted codes were named in terms of five general concepts including personal factors, organizational and environmental factors, psychological factors, skill factors, and work factors. The codes along with the mentioned categories are listed in Table 1:

Table 1

Main Final Extracted Themes from Qualitative Analysis

\begin{tabular}{|c|c|c|c|c|c|}
\hline Row & Main theme & Codes & Rows & $\begin{array}{c}\text { Main } \\
\text { themes }\end{array}$ & Codes \\
\hline 1 & \multirow{7}{*}{ Personal factors } & Gender & 27 & & $\begin{array}{l}\text { Employment in private clinics as a } \\
\text { source of income }\end{array}$ \\
\hline 2 & & Marital status & 28 & & $\begin{array}{c}\text { Time constraints due to spending a } \\
\text { lot of time in the personal surgery } \\
\text { office }\end{array}$ \\
\hline 3 & & Age & 29 & & $\begin{array}{l}\text { Multiple memberships in scientific } \\
\text { committees }\end{array}$ \\
\hline 4 & & Work experience & 30 & & $\begin{array}{l}\text { Lack of transparency in the duties } \\
\text { of the faculty of the medical department }\end{array}$ \\
\hline 5 & & Non-native professors & 31 & & $\begin{array}{l}\text { Lack of proper incentive and } \\
\text { penalty dimension }\end{array}$ \\
\hline 6 & & Personality traits & 32 & & $\begin{array}{l}\text { Administrative bureaucracy for } \\
\text { presenting articles and research }\end{array}$ \\
\hline 7 & & IQ & 33 & & $\begin{array}{l}\text { The dominance of relationships in } \\
\text { determining the position of individuals }\end{array}$ \\
\hline 8 & \multirow{4}{*}{$\begin{array}{l}\text { Organizational } \\
\text { and environmental } \\
\text { factors }\end{array}$} & $\begin{array}{l}\text { Support from organizational } \\
\text { officials }\end{array}$ & 34 & & Limited promotion classes \\
\hline 9 & & Rules and regulations & 35 & & $\begin{array}{l}\text { High levels of obligatory working } \\
\text { hours of faculty members }\end{array}$ \\
\hline 10 & & University management style & 36 & & $\begin{array}{l}\text { Weak management knowledge of } \\
\text { medical universities heads }\end{array}$ \\
\hline 11 & & Low job diversity & 37 & & High student admission \\
\hline
\end{tabular}




\begin{tabular}{|c|c|c|c|c|}
\hline 12 & & $\begin{array}{l}\text { Large number of organizational } \\
\text { levels }\end{array}$ & 38 & $\begin{array}{l}\text { Use of inexperienced people as } \\
\text { professors }\end{array}$ \\
\hline 13 & & $\begin{array}{c}\text { Low number of organizational } \\
\text { positions }\end{array}$ & 39 & $\begin{array}{c}\text { Lack of attention to EQ and mere } \\
\text { emphasis on IQ }\end{array}$ \\
\hline 14 & & Low wages & 40 & Ignorance of medical errors \\
\hline 15 & & $\begin{array}{c}\text { Incompatibility of work and } \\
\text { employment }\end{array}$ & 41 & $\begin{array}{l}\text { Prioritizing of economic and } \\
\text { financial factors for physicians }\end{array}$ \\
\hline 16 & & $\begin{array}{c}\text { Changes in organizational } \\
\text { structure }\end{array}$ & 42 & Severity of clinical actions \\
\hline 17 & & Full time or part-time job & 43 & $\begin{array}{l}\text { High work stress due to the nature } \\
\text { of the job }\end{array}$ \\
\hline 18 & & $\begin{array}{l}\text { The dominant relationships in } \\
\text { promotion }\end{array}$ & 44 & $\begin{array}{l}\text { Prolonged study time of the } \\
\text { medical department }\end{array}$ \\
\hline 19 & \multirow{5}{*}{$\begin{array}{l}\text { psychological } \\
\text { factors }\end{array}$} & Job stress & 45 & $\begin{array}{l}\text { The medical title is valuable and } \\
\text { there is no need to upgrade }\end{array}$ \\
\hline 20 & & Dissatisfaction & 46 & $\begin{array}{l}\text { Focus on the educational } \\
\text { dimension and not paying attention to } \\
\text { other dimensions }\end{array}$ \\
\hline 21 & & $\begin{array}{l}\text { Inappropriate social } \\
\text { relationships }\end{array}$ & 47 & $\begin{array}{l}\text { Specific criteria of medical } \\
\text { research and incompatibility with } \\
\text { morale }\end{array}$ \\
\hline 22 & & Not enjoying work & 48 & $\begin{array}{l}\text { The high cost of medical } \\
\text { procedures }\end{array}$ \\
\hline 23 & & Lack of success in work & 49 & $\begin{array}{l}\text { Lack of group research in medical } \\
\text { fields }\end{array}$ \\
\hline 24 & \multirow{3}{*}{ Skill factors } & $\begin{array}{l}\text { Lack of skill in using } \\
\text { specialized software }\end{array}$ & 50 & $\begin{array}{l}\text { Weak research science in the } \\
\text { medical department }\end{array}$ \\
\hline 25 & & Lack of English proficiency & 51 & $\begin{array}{l}\text { Admission of people with low IQ } \\
\text { to the medicine }\end{array}$ \\
\hline 26 & & Weakness in public speaking & & \\
\hline
\end{tabular}

After preparing the questionnaire, 10 experts who had experience in this field, knowledge of the issue, and sufficient motivation to participate in the research process, were selected as the sample.

After calculating the mean of the experts' views obtained from the first questionnaire, the difference of opinion of each expert was calculated from the mean and this calculated difference was recorded for each expert and the second questionnaire was obtained like the first one based on recording the scores.

In the first questionnaire, a request was made to submit new proposals. In this case, after reevaluating every expert's previous point of view, new results were obtained according to the answers of other experts. Finally, according to the views presented in the first stage and its comparison with the results of this stage, if the difference between the two stages was less than the threshold of .2, the survey process would be stopped. In the survey, the difference of opinion in the first and second stages was less than the threshold (less than .2); therefore, the survey was stopped in the second stage.

In order to confirm or reject the indicators, a limit was considered an indication of acceptance or agreement. In this study, according to the law of 30-70, the acceptable limit for the criterion was about $70 \%$ above the average. Given that the upper limit of the mean was five, the components whose mean score was equal to or greater than 3.5 were considered the final indicator. Therefore, the final criteria are presented in Table 2 and the initial research model is approved. 
Table 2

Final Indicators of the Research Model

\begin{tabular}{|c|c|c|c|}
\hline Main theme & Symbol & Sub-theme & Symbol \\
\hline \multirow{6}{*}{ Personal factors } & \multirow{6}{*}{$\mathrm{C} 1$} & Sex & $\mathrm{C} 11$ \\
\hline & & Marital status & $\mathrm{C} 12$ \\
\hline & & Age & $\mathrm{C} 13$ \\
\hline & & Work experience & C14 \\
\hline & & Personality traits & $\mathrm{C} 15$ \\
\hline & & IQ & C16 \\
\hline \multirow{6}{*}{$\begin{array}{c}\text { Organizational and } \\
\text { environmental } \\
\text { factors }\end{array}$} & \multirow{6}{*}{$\mathrm{C} 2$} & University management & $\mathrm{C} 21$ \\
\hline & & Rules and regulations & $\mathrm{C} 22$ \\
\hline & & Organizational structure & $\mathrm{C} 23$ \\
\hline & & Salaries and benefits & $\mathrm{C} 24$ \\
\hline & & Type of employment & $\mathrm{C} 25$ \\
\hline & & The dominant relationships in promotion & $\mathrm{C} 26$ \\
\hline \multirow{4}{*}{$\begin{array}{l}\text { Psychological } \\
\text { factors }\end{array}$} & \multirow{4}{*}{$\mathrm{C} 3$} & $\begin{array}{c}\text { Job stress } \\
\end{array}$ & C31 \\
\hline & & Inappropriate social relationships & $\mathrm{C} 32$ \\
\hline & & Not enjoying work & $\mathrm{C} 33$ \\
\hline & & Lack of success in work & $\mathrm{C} 34$ \\
\hline \multirow{6}{*}{ Work factors } & \multirow{6}{*}{$\mathrm{C} 4$} & Prioritizing work in the personal surgery office & $\mathrm{C} 41$ \\
\hline & & Multiple memberships in scientific committees & $\mathrm{C} 42$ \\
\hline & & Lack of proper incentive and penalty dimension & $\mathrm{C} 43$ \\
\hline & & Ignorance of medical errors & $\mathrm{C} 44$ \\
\hline & & Priority of economic and financial factors among physicians & $\mathrm{C} 45$ \\
\hline & & The value of the title of doctor and the lack of need for promotion & $\mathrm{C} 46$ \\
\hline \multirow{3}{*}{ Skill factors } & \multirow{3}{*}{$\mathrm{C} 5$} & Lack of skills in specialized software & C51 \\
\hline & & Lack of English proficiency & $\mathrm{C} 52$ \\
\hline & & Weakness in public speaking & C53 \\
\hline
\end{tabular}

\section{The Second Level (Quantitative Phase)}

In order to use the confirmatory factor analysis test to measure the variables, the statistical distribution of the questionnaire items must first be checked. To test the normality of the distribution, the Kolmogorov-Smirnov test was used. The result of this test was the existence of a normal distribution in all research variables.

In what follows, the results of the confirmatory factor analysis of the first and second stages, the research variables were changed to multivariate form by the LISREL software. Figure 2 shows the model of measuring the input structures in the standard estimation mode. The estimated results (lower part of Figure) indicate the relative suitability of the indicators. 


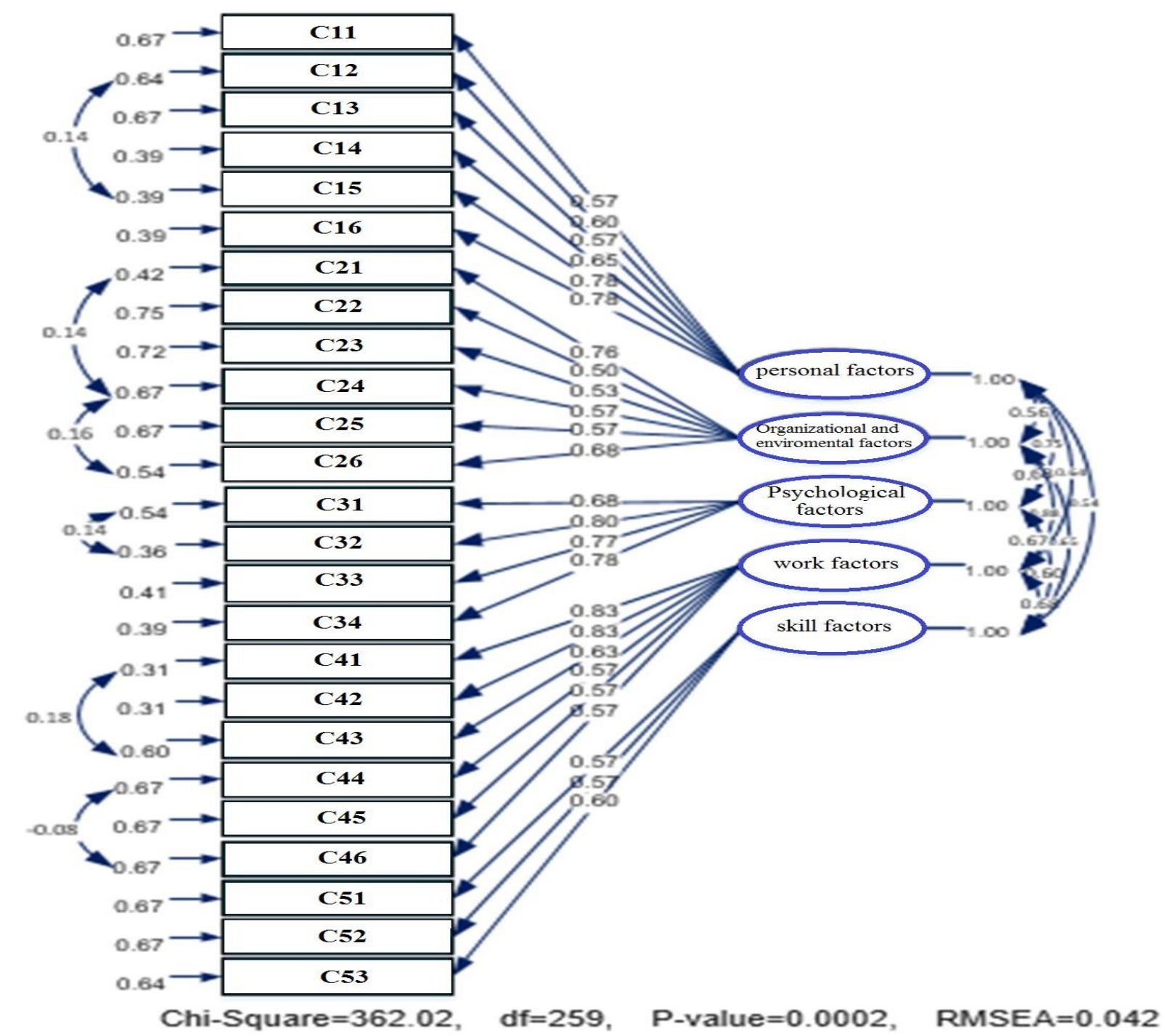

Figure 2. The model of measuring research structures in the standard estimation mode in the first stage

Figure 3 shows the model in terms of significant coefficients. This model is presented to show whether the relationship between factors and index is significant or not. As can be seen, all the obtained coefficients are significant, because the value of the significance test greater than 1.96 or less than 1.96 indicates the significance of the relationship. 


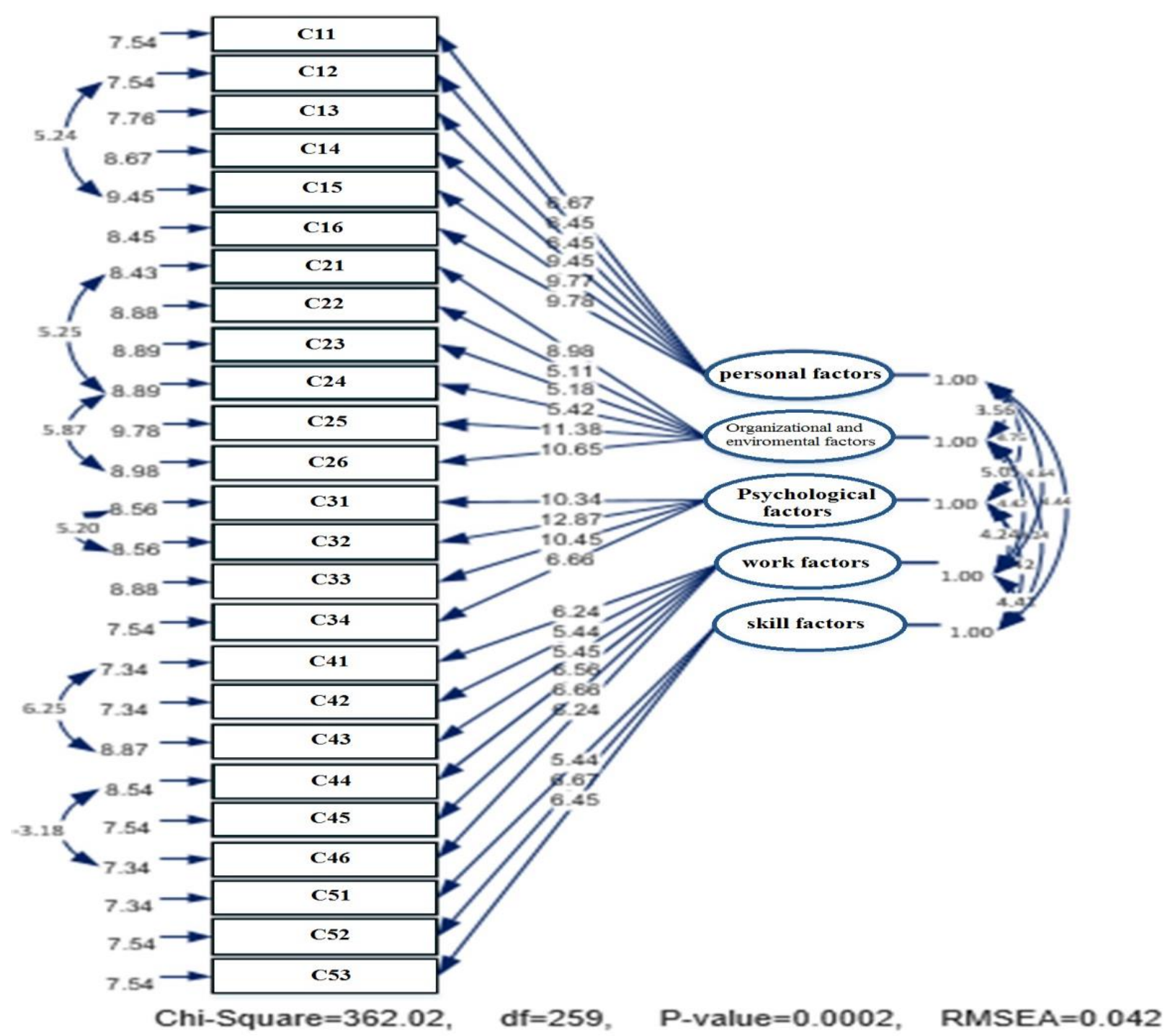

Figure 3. Model of measuring the research structure in a significant mode in the first stage

In the factor analysis of second ranking of the sub-factors, the main variable of the recession of faculty members was obtained. Figure 4 shows the model of measuring the recession structure of faculty members in standard estimation mode and significant mode. The estimated results (lower part of Figure) indicate the relative suitability of the indicators. 


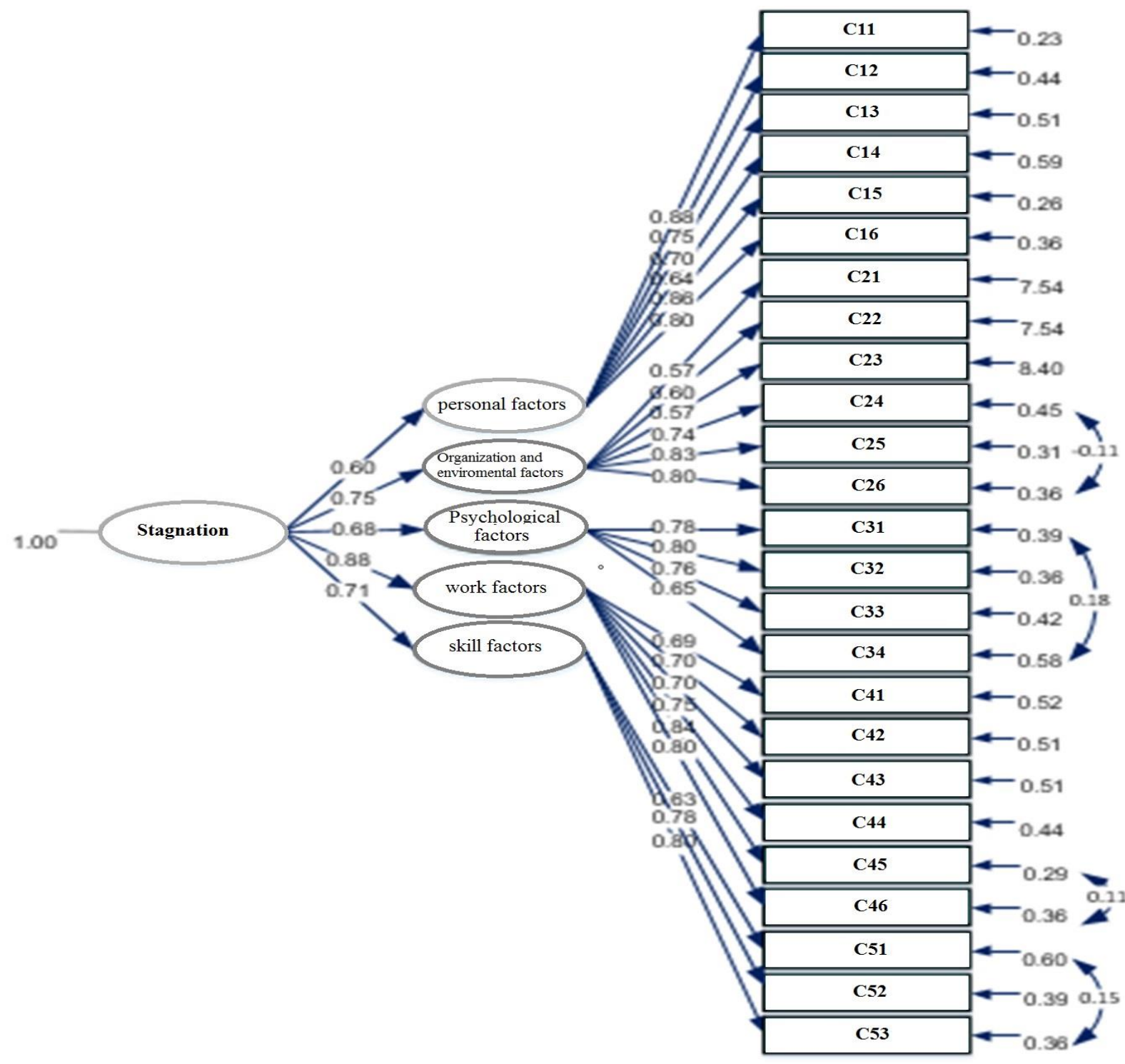

Chi-Square $=322.05, \quad \mathrm{df}=266, \quad \mathrm{P}$-value $=0.0000, \quad$ RMSEA $=0.031$

Figure 4. Model of measuring the recession structure in the second standard estimation mode

Figure 5 of the model shows the recession of faculty members based on the obtained significant coefficients and parameters. This model is presented to show whether the relationship between factors and index is significant or not. As Figure 5 shows, all the obtained coefficients in significant mode are significant for all components, because the value of the significance test greater than 1.96 or less than -1.96 indicates the significance of the relationship. 


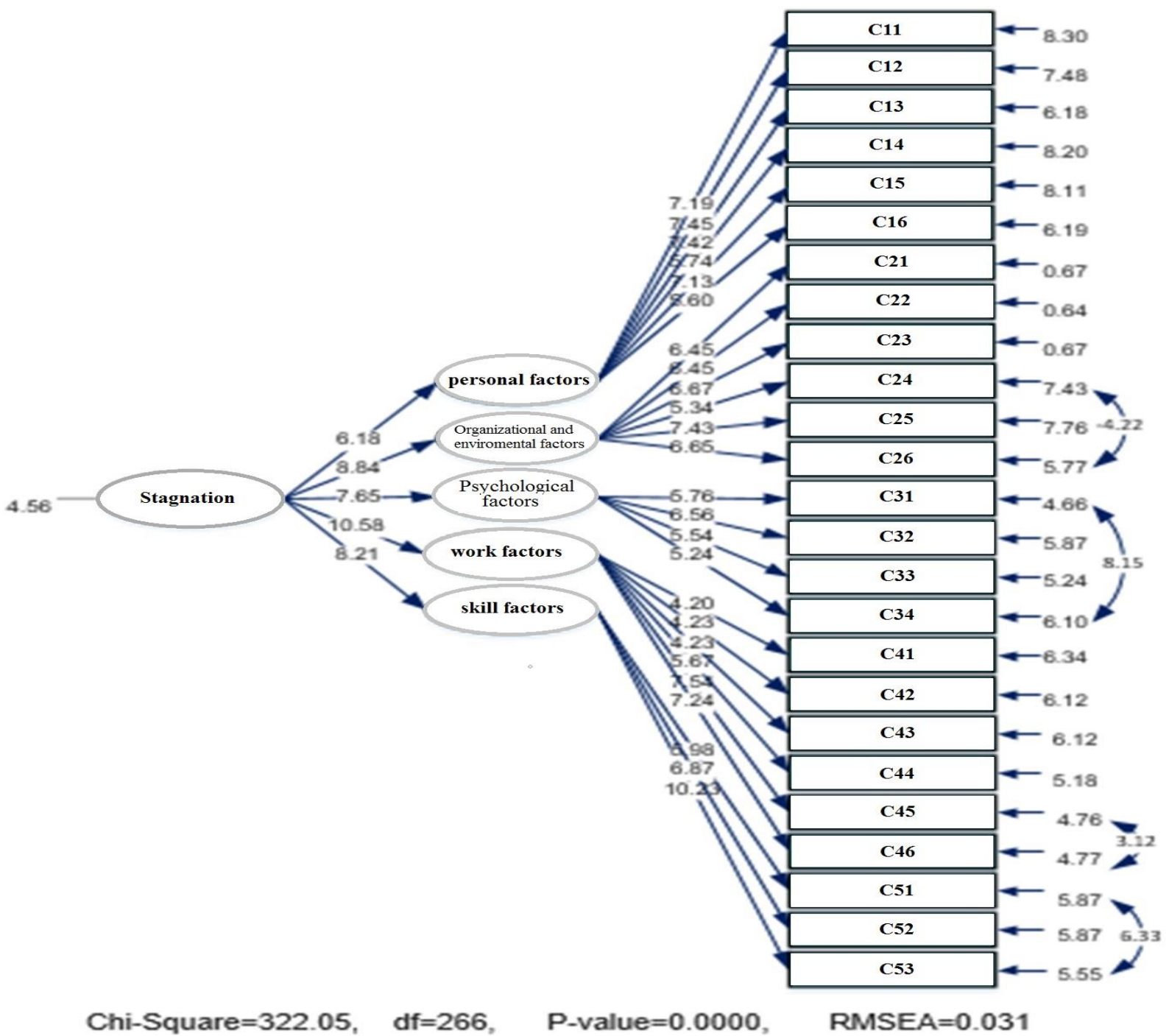

Figure 5. Model of measuring the recession structure in the second significant mode

Then, Friedman test was used to rank the factors affecting the recession of faculty members. The results of the Friedman test can be seen in Table 3 for the ranking of factors affecting the recession of faculty members.

Table 3

Friedman Test Results for Ranking Factors Affecting Faculty Members' Recession

\begin{tabular}{lcc}
\hline The main dimensions of the model & Mean ranking & Ranking \\
\hline Personal factors & 3.15 & 5 \\
Organizational and environmental factors & 4.56 & 3 \\
Psychological factors & 3.43 & 4 \\
Work factors & 6.46 & 1 \\
Skill factors & 6.11 & 2 \\
\hline
\end{tabular}

According to Table 3, given that the significance level is .000, the difference between mean ranks could be concluded. Rejecting the null hypothesis with a $99 \%$ probability, it can be concluded that the difference between the mean rankings is significant. The highest mean rank (6.46) is assigned to the work factors and the lowest one (3.15) is assigned to personal factors related to the recession of faculty members in Ardabil University of Medical Sciences. 


\section{Conclusions}

The results of the analysis of the data obtained by interview and Grounded Theory and finally the Delphi technique showed that the most important dimensions of the recession of the faculty members of the Ardabil University of Medical Sciences were identified in five general components and 25 indicators as follows:

Table 4

The Most Important Dimensions of the Recession of the Faculty Members of the Ardabil University of Medical Sciences

\begin{tabular}{|c|c|c|c|}
\hline Main factor & Subcomponent & Main factor & Subcomponent \\
\hline \multirow{4}{*}{ Psychological factors } & Job stress & \multirow{6}{*}{ Personal factors } & Sex \\
\hline & Inappropriate social relationships & & Marital status \\
\hline & Not enjoying work & & Age \\
\hline & Lack of success & & Work experience \\
\hline \multirow{6}{*}{ Work factors } & $\begin{array}{l}\text { Prioritizing work in the personal } \\
\text { surgery office }\end{array}$ & & Personal traits \\
\hline & $\begin{array}{l}\text { Multiple memberships in scientific } \\
\text { committees }\end{array}$ & & IQ \\
\hline & $\begin{array}{l}\text { Lack of proper incentive and } \\
\text { punishment dimension }\end{array}$ & \multirow{7}{*}{$\begin{array}{l}\text { Organizational and } \\
\text { environmental factors }\end{array}$} & University management \\
\hline & Ignorance of medical errors & & Rules and regulations \\
\hline & $\begin{array}{l}\text { Priority of economic and financial } \\
\text { factors among physicians }\end{array}$ & & Organizational structure \\
\hline & $\begin{array}{l}\text { The value of the title of doctor and the } \\
\text { lack of need for promotion }\end{array}$ & & Salaries and benefits \\
\hline \multirow{3}{*}{ Skill factors } & Lack of skills in specialized software & & Type of employment \\
\hline & Lack of English proficiency & & \multirow{2}{*}{$\begin{array}{l}\text { The dominant relationships in } \\
\text { promotion }\end{array}$} \\
\hline & Weakness in public speaking & & \\
\hline
\end{tabular}

Then, by factor analysis, the validity of the designed model and the research indicators were measured, which showed the validity of the model in the studied population. Finally, according to the analysis of the final model, the factors affecting the recession of faculty members in Ardabil University of Medical Sciences were designed as presented in Figure 6. 


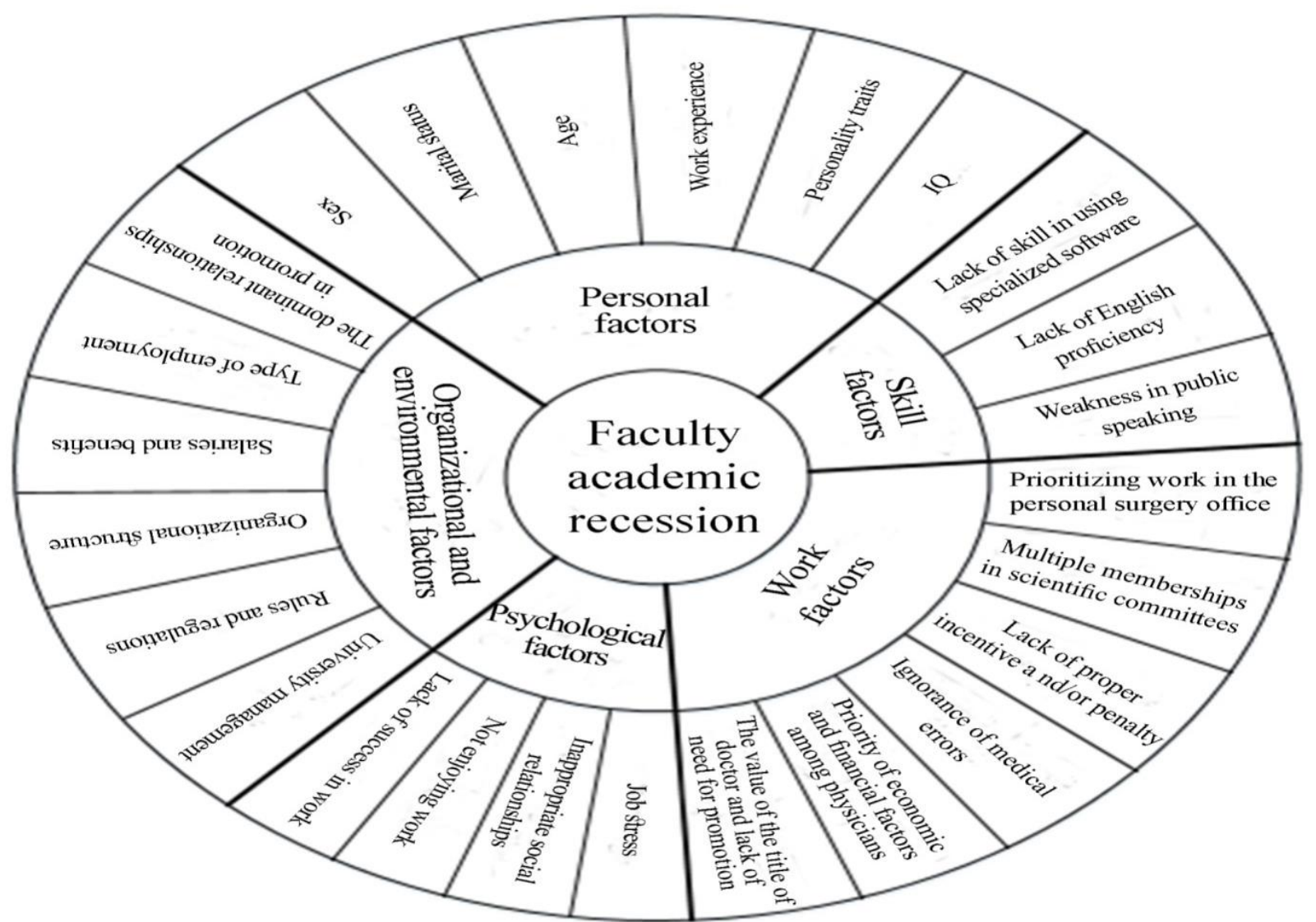

Figure 6. The final model of the factors affecting the recession of faculty members of Ardabil University of Medical Sciences

Finally, with Friedman test, the most important factors affecting the recession of the faculty members of Ardabil University of Medical Sciences were ranked. Based on its results, the main factors affecting the recession of faculty members of Ardabil University of Medical Sciences are: work factors, skill factors, organizational and environmental factors, psychological factors, and personal factors, respectively.

According to the results, the most important factor in the recession of faculty members is the work factors that are related to the work life of the individuals. Since the most important source of scientific organizations is human resources, it is necessary for universities to measure the recession from time to time and also analyze the reasons of weakening their faculty members and based on its results try to examine the causes and ways to deal with it (Ahadi et al., 2015).

Faculty members are in recession when they do not feel any interest or pleasure in their work. Therefore, by enriching and developing training courses to improve the scientific rank and develop the individual morale of professors by giving scholarships and continuing short-term and long-term training courses at home and abroad can play an important role in reducing the recession (Norouzi et al., 2016).

Raising the awareness of professors about job recession and the affecting factors is necessary to restrain professors from leaving the university or productivity decline in their job. It is suggested that workshops be held for faculty members focusing on the career plateau and teach them ways out of the recession (Khanifar, 2006). This coaching should include trainings about individual skills of employees to master job stress in order to reduce the amount of psychological stress among faculty members (Norouzi et al., 2016). 
By creating hope and vitality and constructive interactions with other universities and professors, it is possible to create a competitive atmosphere among faculty members. It is necessary to communicate with other universities along with holding appropriate training courses to improve knowledge and keep faculty members up to date.

Proper evaluation of Universities' performance through comprehensive models (Ketabchi \& Valles, 2018) and the performance faculty members include individual needs, skills, and values are the important factors in reducing recession. For example, AMO model is suggested to study ability, opportunity and motivation in the Universities (Mohammadi \& Faskhodi, 2020). The proper use of the incentive and penalty system using new management practices, the creation of facilities and amenities to provide housing and welfare centers, and the participation of faculty members in decision-making cause the job recession to decline (Shariatnejad et al., 2017). The use of various professors and the permission to participate and be a member of scientific committee plays a very important role in removing the faculty members from job recession. Therefore, university administrators should take the necessary actions in this regard and not just use the multiple and permanent memberships in scientific committees (Khanifar, 2006).

Nowadays, financial and economic issues are top priorities among some physicians, which have led to recession in their careers. It is better for university administrators to try harder to financially persuade the professors (Mobini \& Abbaspour, 2014). For faculty members at Ardabil University of Medical Sciences, working in a surgery office is much more important than working at a university. The university administration can prevent professors from paying attention to the office by obliging them and setting up work schedules in private offices.

It happens a lot that the managers of the Medical Council neglect the mistakes of doctors and they ignore many of these mistakes. This has led to a lack of attention to participation in retraining and extensive scientific studies, and ultimately to the neglect of errors and recession among physicians. Supervisory committees need to be more decisive in this regard.

\section{References}

Abraham, N. Nwovuhoma, J. J., \& Malik, C. A. (2016). Career plateau and employee performance in secondary schools in rivers state. African International Journal of Educational Learning, 4(8), 168-178.

Ahadi, A., Shirazi, M., Sadr, S. Sh., \& Mojtahedzadeh, R. (2015). The relationship between readiness to change the performance of the faculty members of the basic sciences of the Faculty of Medicine of Tehran University of Medical Sciences with their job burnout. Iranian Journal of Forensic Medicine, 21(1), 13-19.

Allen, T. D., Eby, L. T., Poteet, M. L., Lentz, E., \& Lima, L. (2014). Career benefits associated with mentoring for protégés: A meta-analysis. Journal of Applied Psychology, 89(1), 127-136.

Alrahlah, A. (2016). The impact of motivational factors on research productivity of dental faculty members: A qualitative study. Journal of Taibah University Medical Sciences, 11(5), 448-455.

Al-Omari, A. A. (2020). Sultan Qaboos University faculty members' perceptions of strategic planning effectiveness helped improve their department chairperson practice as instructional leaders. Educational Studies in the New Millennium, 3(2), 4657.

Burke, R. I., \& Mikkelsen, A. (2006). Examining the career plateau among police officers. International Journal of Police Strategy and Management, 29(4), 691-703

Çelo, E., Danaj, L., Çerkezi, E., \& Çelo, J. (2019). Leading new generation knowledge while reforming the teaching process: A study case in Albanian Universities. Studies in Educational Management, 3, 1-12. https://doi.org/10.32038/SEM.2019.03.01

Drucker-Godard, C., Fouque, T., Gollety, M., \& Le Flanchec, A. (2015). Career plateauing, job satisfaction and commitment of scholars in French universities. Public Organization Review, 15(3), 335-351. 
Ketabchi, E., \& Valles, R. S. (2018). A comprehensive model for evaluating the performance of universities, Management and Business Research Quarterly, 5, 47-68. https://doi.org/10.32038/mbrq.2018.01.05

Khanifar, H. (2006). Examining the psychological dimensions of the career plateau and providing practical solutions for existing. Management of Organizational Culture, 4(12), 83-111.

Kreuter, E. (2004). Why career plateaus are healthy? 22, 87. Retrieved from http://www.lucaonline.com/ cpajournal/ old.

Magner, N., Welker, R. B., \& Campbell, T. L. (2011). Testing a model of cognitive budgetary participation processes in a latent variable structural equations framework. Accounting and Business Research, 27(1), 41-50.

Mahmoudi, M. H., \& Qaslani, R. (2015). The relationship between teachers' artificial intelligence, reflection and burnout. Applied Language Studies, 6(1), 89-116.

Mobini, M., \& Abbaspour, A. (2014). Development of effective and useful faculty members for improving the quality of universities and higher education institutions. Paper presented at the First National Conference on Quality Assessment in Academic Systems. Sharif University, Tehran, Iran.

Mohammadi, M., \& Faskhodi, A. A. (2020). Modeling AMO factors affecting English teachers' performance using system dynamics. Language Teaching Research Quarterly, 16, 22-39. https://doi.org/10.32038/ltrq.2020.16.02

Norouzi, A. M., Zare, A. R., \& Shir Ali, R. (2016). Effective factors on the creation of career plateau in faculty members of physical education faculties of public universities in Iran. Journal of Research and Planning in Higher Education, 22(3), 1935 .

Shariatnejad, A., Ismaili, M. R., \& Arefnejad, M. (2017). Identifying and prioritizing the causes of occupational plateau in governmental organizations using fuzzy Delphi method. Scientific Research of the Ministry of Science, 22(98), 166-145.

Saleh Ardestani, A., \& Seyed Naghavi, M. A. (2016). Explaining the relationship between career plateau and organizational indifference and willingness of staff to leave their jobs. General Management Research, 5(31), 160-145.

Tabarsa, Gh. A., Rezaeian, A., Hadizadeh Moghadam, A., \& Jamali Nazari, A. (2014). Designing and explaining the career plateau model in governmental organizations. Management of Governmental Agencies, 3 (1), 90-103.

Tremblay, M., \& Roger, A. (2004). Career plateauing relations: The moderating role of job scope, role ambiguity and participating among Canadian managers, International Journal of Human Resource Management, 15(6), 996-1017.

Vaseghi, A., \& Ahmadlou, M. (2019). Investigating the effect of organizational commitment on the employee performance with the mediating role of organizational happiness. Journal of Career Studies, 2(1), 9-24. 